\title{
PENGELOLAAN ALOKASI DANA DESA DALAM MEWUJUDKAN GOOD GOVERNANCE
}

\author{
Teti Anggita Safitri ${ }^{1}$, Rigel Nurul Fathah ${ }^{2}$ \\ Universitas Aisyiyah Yogyakarta \\ tetianggita@unisayogya.ac.id, rigelnurul@unisayogya.ac.id
}

\begin{abstract}
This study focuses attention on the management of Village Fund Allocation This study aims to 1) Know whether the management of Village Fund Allocation in Sardonoharjo Ngaglik Sleman Village in 2017 has applied the principles of Good Governance. 2) Knowing the stages of managing Village Fund Allocation in Sardonoharjo Ngaglik Sleman Village in 2017. 3) Knowing the Village Financial Performance in Sardonoharjo Ngaglik Sleman Village in 2017. This research is a qualitative research in which the researcher conducted in-depth interviews with the informants to gather information so that objective research on village fund allocation was obtained, this was done considering that in-depth interviews were the right research strategy to find out in detail both the village government and village officials. The conclusion of this study is that 1) The Management System of Village Fund Allocation in Sardonoharjo Village has applied the principles of good governance. 2). Stages of Management of Village Fund Allocation apply Planning, Implementation and Accountability Village Fund Allocation is technically and administratively good enough, but in terms of administrative accountability constrained by delays in reports from the dukuh and the village parties have difficulty in implementing the Village Financial System (SISKEUDES). 3) Measurement of Village Financial Performance in Sardonoharjo Village is based on the effectiveness level of $97 \%$ which means effective.
\end{abstract}

\section{Keyword: Good Governance, Village Fund Allocation, Village Financial Performance}

Abstraksi. Penelitian ini memfokuskan perhatian pada pengelolaan Alokasi Dana Desa Penelitian ini bertujuan untuk 1) Mengetahui apakah pengelolaan Alokasi Dana Desa di Desa Sardonoharjo Ngaglik Sleman tahun 2017 telah menerapkan prinsip prinsip Good Governance. 2) Mengetahui tahapan pengelolaan Alokasi Dana Desa dan kendalanya di Desa Sardonoharjo Ngaglik Sleman tahun 2017. 3) Mengetahui Kinerja Keuangan Desa di Desa Sardonoharjo Ngaglik Sleman tahun 2017. Penelitian ini merupakan penelitian kualitatif dimana peneliti melakukan wawancara mendalam kepada narasumber untuk menggali informasi sehingga diperoleh penelitian yang obyektif mengenai alokasi dana desa, hal ini dilakukan mengingat wawancara mendalam merupakan strategi penelitian yang tepat untuk mengetahui secara mendetail baik dari pihak pemerintah desa dan perangkat desa. Kesimpulan penelitian ini bahwa 1) Sistem Pengelolaan Alokasi Dana Desa di Desa Sardonoharjo telah menerapkan prinsip-prinsip good governance. 2). Tahapan Pengelolaan Alokasi Dana Desa menerapkan Perencanaan, Pelaksanaan dan Pertanggungjawaban Alokasi Dana Desa secara teknis maupun administrasi sudah cukup baik, namun dalam hal pertanggungjawaban administrasi terkendala dengan keterlambatan laporan dari pedukuhan dan pihak desa agak kesulitan dalam menerapkan Sistem Keuangan Desa (SISKEUDES). 3) Pengukuran Kinerja Keuangan Desa di Desa Sardonoharjo didasarkan pada tingkat efektivitasnya yaitu sebesar 97\% yang berarti efektif.

\section{Kata kunci: Good Governance, Alokasi Dana Desa, Kinerja Keuangan Desa}




\section{PENDAHULUAN}

Dalam Permendagri No 113 Tahun 2014 tentang Pengelolaan Keuangan Desa menyebutkan bahwa Alokasi Dana Desa (ADD) merupakan salah satu bagian pendapatan desa yang ditetapkan dalam APBdes, yang berasal dari APBD dengan jumlah yang dihitung sesuai dengan kebutuhan desa dengan jumlah anggaran yang ditetapkan oleh Peraturan Bupati, Alokasi Dana Desa merupakan wujud kepercayaan pemerintah kabupaten kepada pemerintah desa sebagai daerah otonom untuk mengelola anggaran kegiatan yang dilakukan oleh desa baik itu berbentuk kegiatan fisik maupun tidak yang pelaksanaannya sesuai dengan peraturan yang berlaku, dengan harapan agar tercipta otonomi asli, demokratisasi, peningkatan pelayanan, dan pemberdayaan masyarakat (Astuti, 2012).

Tugas pemberian bantuan dari pemerintah, pemerintah provinsi, dan pemerintah kabupaten kepada desa harus disertai dengan pembiayaan, sarana dan prasarana serta sumber daya manusia (Solekhan, 2012). Oleh karena itu terdapat anggaran sebagai modal pembangunan untuk kesejahteraan masyarakat yang dikenal dengan Alokasi Dana Desa. Tujuan utama ADD adalahuntuk mempercepat pembangunan tingkat Desa baik pembangunan fisik(sarana-prasarana maupun sumber daya manusia.

Menurut Direktur Jenderal Perimbangan Keuangan Kementerian Keuangan RI, Dr. Boediarso Teguh Widodo dalam acara Sosialisasi Kebijakan Dana Desa menjelaskan bahwa adanya peningkatan dana desa sebesar 225\% pada tahun 2016. Dimana pada tahun 2015 Dana Desa Sleman sebesar Rp 28 miliar maka pada tahun 2016 meningkat menjadi Rp 63,01 miliar, kebijakan pengalokasian dana desa yang semakin besar dalam struktur anggaran keuangan nasional ini merupakan salah satu kebijakan pemerintah yang revolusioner dan radikal. Kebijakan ini dikatakan radikal karena merupakan perubahan yang sangat drastis dalam penganggaran dan belum pernah dilakukan sebelumnya. Adanya dana desa yang diturunkan langsung dari pusat langsung ke desa ini menjadi peluang untuk meningkatkan pembangunan di desa, dimana dana desa merupakan bentuk keberpihakan pemerintah pada pembangunan di desa. Hal ini menunjukkan perubahan paradigma pembangunan di Indonesia yang selama ini terkonsentrasi di kota-kota besar berubah menjadi di desa-desa. Pemerintah berharap dana desa bisa dikerjakan oleh masyarakat sendiri sehingga selain membangun sekaligus membuka lapangan kerja apalagi Sleman memiliki potensi sumber daya manusia yang sangat memadai karena merupakan kota pelajar dan terdapat beberapa universitas yang berdiri di wilayah Sleman.

Dari penjelasan diatas yaitu adanya peningkatan dana desa yang cukup signifikan mengingat bahwa desa yang dulunya sebelum melaksanakan pembangunan hanya mendapat bantuan keuangan yang terbatas dan pengelolaannya masih sangat sentralistis oleh satuan instansi pemerintahan, akan tetapi setelah kebijakan alokasi dana desa 
diberlakukan sekarang ini, desa mendapatkan alokasi anggaran yang cukup besar dan pengelolaannya secara mandiri, sehingga kemampuan desa secara internal untuk mengelola alokasi dana tersebut masih dipertanyakan.

Fenomena ini menarik untuk diteliti karena pertanggungjawaban pengelolaan keuangan desa yaitu Alokasi Dana Desa pada praktiknya belum sesuai dengan ketentuan yang berlaku (pengelolaan keuangan desa), sehingga perlu dikaji dan dianalisa bagaimana sebenarnya pengelolaan alokasi dana desa pada tingkat implementasi di lapangan dan bagaimana Kinerja Keuangan Dana Desa. Kendala-kendala apa yang dihadapi oleh para pelaku atau aparat pengelola, serta bagaimana menemukan solusi untuk mengatasi permasalahan/kendala tersebut. Peneliti mencoba untuk melakukan penelitian di Desa Sardonoharjo Ngaglik Sleman sebagai obyek penelitian karena Sleman memperoleh peningkatan dana desa yang cukup signifikan sebesar $225 \%$,. Selain itu terdapat beberapa Universitas yang berdiri di wilayah Sleman, ini menunjukkan bahwa wilayah Sleman memiliki potensi sumber daya manusia yang memadai.

Berdasarkan latar belakang yang telah dipaparkan di atas, maka yang menjadi permasalahan dalam penelitian ini adalah : 1) Apakah pengelolaan Alokasi Dana Desa di Desa Sardonoharjo Ngaglik Sleman tahun 2017 telah menerapkan prinsip prinsip Good Governance. 2) Bagaimana tahapan pengelolaan Alokasi Dana Desa dan kendalanya di Desa Sardonoharjo Ngaglik Sleman tahun 2017. 3)
Bagaimana Kinerja Keuangan Desa di Desa Sardonoharjo Ngaglik Sleman tahun 2017.

\section{KAJIAN TEORITIS}

Good Governance menurut UNDP (United Nations Development Program) adalah suatu penyelenggaraan manajemen pembangunan yang solid dan bertanggung jawab yang sejalan dengan prinsip demokrasi dan pasar yang efisien, penghindaran salah alokasi dana investasi dan pencegahan korupsi baik secara politik maupun secara administratif menjalankan disiplin anggaran serta penciptaan legal dan politican framework bagi tumbuhnya aktifitas usaha.

Kunci utama memahami good governance adalah pemahaman atas prinsip-prinsip di dalamnya. Bertolak dari prinsip-prinsip ini akan didapatkan tolak ukur kinerja suatu pemerintahan. Baikburuknya pemerintahan bisa dinilai bila ia telah bersinggungan dengan semua unsur prinsip-prinsip good governance. Menurut UNDP (United Nations Development Program) dalam Nurul, Rigel (2017), prinsip-prinsip good governance diantaranya, yaitu :

\section{Partisipasi Masyarakat (Participation)}

Semua warga masyarakat mempunyai suara dalam pengambilan keputusan, baik secara langsung maupun melalui lembagalembaga perwakilan sah yang mewakili kepentingan mereka. Partisipasi menyeluruh tersebut dibangun berdasarkan kebebasan berkumpul dan mengungkapkan pendapat, serta kapasitas untuk 
berpartisipasi secara konstruktif. Partisipasi bermaksud untuk menjamin agar setiap kebijakan yang diambil mencerminkan aspirasi masyarakat. Dalam rangka mengantisipasi berbagai isu yang ada, pemerintah daerah menyediakan saluran komunikasi agar masyarakat dapat mengutarakan pendapatnya.

2. Tegaknya Supremasi Hukum (Rule of Law)

Partisipasi masyarakat dalam proses politik dan perumusanperumusan kebijakan publik memerlukan sistem dan aturanaturan hukum. Sehubungan dengan itu, dalam proses mewujudkan cita good governance, harus diimbangi dengan komitmen untuk menegakkan rule of law dengan karakter-karakter antara lain sebagai berikut: Supremasi hukum (the supremacy of law), Kepastian hukum (legal certainty), Hukum yang responsip, Penegakkan hukum yang konsisten dan nondiskriminatif, Indepedensi peradilan. Kerangka hukum harus adil dan diberlakukan tanpa pandang bulu, termasuk di dalamnya hukum-hukum yang menyangkut hak asasi manusia

3. Transparansi (Transparency)

Transparansi adalah keterbukaan atas semua tindakan dan kebijakan yang diambil oleh pemerintah. Prinsip transparansi menciptakan kepercayaan timbal-balik antara pemerintah dan masyarakat melalui penyediaan informasi dan menjamin kemudahan di dalam memperoleh informasi yang akurat dan memadai. Tranparansi dibangun atas dasar arus informasi yang bebas. Seluruh proses pemerintahan, lembaga-lembaga dan informasi perlu dapat diakses oleh pihak-pihak yang berkepentingan, dan informasi yang tersedia harus memadai agar dapat dimengerti dan dipantau.

4. Peduli pada Stakeholder/Dunia Usaha

Lembaga-lembaga dan seluruh proses pemerintahan harus berusaha melayani semua pihak yang berkepentingan. Dalam konteks praktek lapangan dunia usaha, pihak korporasi mempunyai tanggungjawab moral untuk mendukung bagaimana good governance dapat berjalan dengan baik di masing-masing lembaganya. Pelaksanaan good governance secara benar dan konsisten bagi dunia usaha adalah perwujudan dari pelaksanaan etika bisnis yang seharusnya dimiliki oleh setiap lembaga korporasi yang ada di dunia. Dalam lingkup tertentu etika bisnis berperan sebagai elemen mendasar dari konsep CSR (Corporate Social Responsibility) yang dimiliki oleh perusahaan. Pihak perusahaan mempunyai kewajiban sebagai bagian masyarakat yang lebih luas untuk memberikan kontribusinya. Praktek good governance menjadi kemudian guidence atau panduan untuk operasional perusahaan, baik yang dilakukan dalam kegiatan internal maupun eksternal 
perusahaan. Internal berkaitan dengan operasional perusahaan dan bagaimana perusahaan tersebut bekerja, sedangkan eksternal lebih kepada bagaimana perusahaan tersebut bekerja dengan stakeholder lainnya, termasuk didalamnya publik.

5. Berorientasi pada Konsensus (Consensus)

Menyatakan bahwa keputusan apapun harus dilakukan melalui proses musyawarah melalui konsensus. Model pengambilan keputusan tersebut, selain dapat memuaskan semua pihak atau sebagian besar pihak, juga akan menjadi keputusan yang mengikat dan milik bersama, sehingga ia akan mempunyai kekuatan memaksa (coercive power) bagi semua komponen yang terlibat untuk melaksanakan keputusan tersebut. Tata pemerintahan yang baik menjembatani kepentingankepentingan yang berbeda demi terbangunnya suatu konsensus menyeluruh dalam hal apa yang terbaik bagi kelompok-kelompok masyarakat, dan bila mungkin, konsensus dalam hal kebijakankebijakan dan prosedur-prosedur.

6. Kesetaraan (Equity)

Kesetaraan yakni kesamaan dalam perlakuan dan pelayanan. Semua warga masyarakat mempunyai kesempatan memperbaiki atau mempertahankan kesejahteraan mereka. Prinsip kesetaraan menciptakan kepercayaan timbalbalik antara pemerintah dan masyarakat melalui penyediaan informasi dan menjamin kemudahan di dalam memperoleh informasi yang akurat dan memadai. Informasi adalah suatu kebutuhan penting masyarakat untuk berpartisipasi dalam pengelolaan daerah. Berkaitan dengan hal tersebut pemerintah daerah perlu proaktif memberikan informasi lengkap tentang kebijakan dan layanan yang disediakannya kepada masyarakat. Pemerintah daerah perlumendayagunakan berbagai jalur komunikasi seperti melalui brosur, leaflet, pengumuman melalui koran, radio serta televisi lokal. Pemerintah daerah perlu menyiapkan kebijakan yang jelas tentang cara mendapatkan informasi.

7. Efektifitas dan Efisiensi (Effectiveness and Efficiency)

Untuk menunjang prinsip-prinsip yang telah disebutkan di atas, pemerintahan yang baik dan bersih juga harus memenuhi kriteria efektif dan efisien yakni berdaya guna dan berhasil-guna. Kriteria efektif biasanya di ukur dengan parameter produk yang dapat menjangkau sebesarbesarnya kepentingan masyarakat dari berbagai kelompok dan lapisan sosial. Agar pemerintahan itu efektif dan efisien, maka para pejabat pemerintahan harus mampu menyusun perencanaanperencanaan yang sesuai dengan kebutuhan nyata masyarakat, dan disusun secara rasional dan terukur. 
Dengan perencanaan yang rasional tersebut, maka harapan partisipasi masyarakat akan dapat digerakkan dengan mudah, karena program-program itu menjadi bagian dari kebutuhan mereka.

8. Akuntabilitas (Accountability)

Akuntabilitas adalah pertangungjawaban pejabat publik terhadap masyarakat yang memberinya kewenangan untuk mengurusi kepentingan mereka. Para pengambil keputusan di pemerintah, sektor swasta dan organisasi-organisasi masyarakat bertanggung jawab baik kepada masyarakat maupun kepada lembaga-lembaga yang memiliki kepentingan. Bentuk pertanggungjawaban tersebut berbeda satu dengan lainnya tergantung dari jenis organisasi yang bersangkutan. Instrumen dasar akuntabilitas adalah peraturan perundang-undangan yang ada, dengan komitmen politik akan akuntabilitas maupun mekanisme pertanggungjawaban, sedangkan instrumen pendukungnya adalah pedoman tingkah laku dan sistem pemantauan kinerja penyelenggara pemerintahan dan sistem pengawasan dengan sanksi yang jelas dan tegas.

9. Visi Strategis (Strategic Vision)

Visi strategis adalah pandanganpandangan strategis untuk menghadapi masa yang akan datang. Para pemimpin dan masyarakat memiliki perspektif yang luas dan jauh ke depan atas tata pemerintahan yang baik dan pembangunan manusia, serta kepekaan akan apa saja yang dibutuhkan untuk mewujudkan perkembangan tersebut. Selain itu mereka juga harus memiliki pemahaman atas kompleksitas kesejarahan, budaya dan sosial yang menjadi dasar bagi perspektif tersebut

Dalam Permendagri No 113

Tahun 2014 tentang Pengelolaan Keuangan Desa disebutkan bahwa : Alokasi Dana Desa adalah dana yang dialokasikan oleh Pemerintah Kabupaten/Kota untuk Desa, yang bersumber dari bagian dana perimbangan keuangan pusat dan daerah yang diterima oleh Kabupaten/Kota.Kemudian pasal penjelas menegaskan bahwa yang dimaksud dengan dana perimbangan keuangan pusat dan daerah yaitu dana yang terdiri dari dana bagi hasil pajak dan sumber daya alam ditambah Dana Alokasi Umum (DAU) setelah dikurangi belanja pegawai. Dalam pasal penjelas pula disebutkan bahwa alokasi Dana Desa adalah $70 \%$ untuk pemberdayaanmasyarakat dan pembangunan serta $30 \%$ untuk Pemerintahan dan Badan Permusyawaratan Desa.

Tahapan pengelolaan ADD diatur secara garis besar mulai dari mekanisme perencanaan, pelaksanaan dan pengawasan.

a. Tahap Perencanaan

Mekanisme perencanaan ADD dimulai dari Kepala Desa selaku penanggungjawab ADD mengadakan musyawarah desa untuk membahas rencana penggunaan ADD yang dihadiri 
oleh unsur pemerintah desa, Badan Permusyawaratan Desa, Lembaga Kemasyarakatan Desa dan tokoh masyarakat, hasil musyawarah tersebut dituangkan dalam Rencana Kerja Pembangunan Desa (RKPDes) yang merupakan salah satu bahan penyusunan APBDes.

b. Tahap Pelaksanaan Pelaksanaan kegiatan sebagaimana ditetapkan dalam APBDes yang pembiayaannya bersumber dari ADD

c. Tahap Pertanggungjawaban

Pertanggungjawaban ADD terintegrasi pertanggungjawaban APBDesa, sehingga bentuk pertanggungjawabannya adalah pertanggungjawaban APBDesa. Namun demikian Tim Pelaksana Tingkat Desa wajib melaporkan pelaksanaan ADD berupa Laporan Pertanggungjawaban Keuangan Desa, Laporan Berkala dan Laporan Akhir ADD.

Kinerja Keuangan Desa diukur dengan tingkat efektivitas. Sesuai dengan Permendagri No. 21 tahun 2011, efektivitas adalah pencapaian hasil program dengan target yang telah ditetapkan, yaitu dengan cara membandingkan keluaran dengan hasil (output-outcome). Outcome adalah segala sesuatu yang mencerminkan berfungsinya keluaran kegiatan pada jangka menengah.

\section{METODE PENELITIAN}

Obyek penelitian ini adalah Desa Sardonoharjo Ngaglik Sleman. Instrumen penelitian untuk memperoleh data kualitatif dan informasi yang valid dan akurat, maka dilakukan dengan wawancara secara mendalam terhadap informan-informan yang dijadikan sumber informasi. Sedangkan informan yang dipilih adalah informan yang terlibat langsung serta memahami dan dapat memberikan informasi (gambaran) tentang pengelolaan Alokasi Dana Desa, yaitu Pemerintah Desa selaku Tim Pelaksana Desa dan Lembaga Pemberdayaan Masyarakat Desa (LPMD) selaku Tim Pelaksana Kegiatan. Sebagai informan dari unsur pemerintah desa, diwakili oleh Kepala Desa, Sekretaris Desa dan Bendahara, sedangkan pihak LPMD diwakili oleh ketua dan anggota yang berkompeten dalam pengelolaan Alokasi Dana Desa. Sementara untuk Kinerja Keuangan Desa menggunakan data APBDes

Metode Pengumpulan Data yaitu melalui pengumpulan data yang utama (untuk mendapatkan data primer) peneliti akan melakukan wawancara secara mendalam. Sedangkan data sekunder dalam penelitian ini adalah APBDesa Sardonoharjo Kecamatan Ngaglik Sleman tahun 2017.

\section{HASIL DAN PEMBAHASAN}

Sistem pengelolaan Alokasi Dana Desa dimaksudkan sebagai upaya untuk mewujudkan tata kelola pemerintahan yang baik (good governance). Pengelolaan ADD sebagai bagian dari pelaksanaan pembangunan di desa, perlu memegang teguh prinsipprinsip yang merupakan indikator good governance tersebut. Oleh karena itu dalam menggambarkan sistem pengelolaan ADD, akan diuraikan lebih lanjut berdasarkan data dan informasi, 
sejauhmana indikator tersebut djalankan di wilayah penelitian.

Dari ketentuan tersebut, menyebutkan bahwa pengelolaan ADD harus dilaksanakan secara terbuka melalui musyawarah desa dan hasilnya dituangkan dalam Peraturan Desa. Ketentuan tersebut menunjukkan komitmen dari stakeholder / pengambil keputusan bahwa pengelolaan ADD harus memenuhi kaidah good governance yang harus dilaksanakan oleh pelaku dan masyarakat desa. Adanya komitmen yang kuat dari Pemerintah Desa Sardonoharjo untuk mengembangkan tingkat partisipasi masyararakat sesuai dengan informasi dari Kepala Desa sebagai berikut :

"Antusiasme masyarakat desa Sardonoharjo sangat luar biasa terlihat dari partisipasi masyarakat ketika dilaksanakan musrembangduk, musrenbangdes, maupun kegiatan lainnya. Semangat membangun kemandirian desa semaikin semarak. Kalau dahulu, Musrembangdes hanya sekedar wacana dan sekedar usulan, sekarang desa dapat menetapkan usulan pembangunan menjadi program dan kegiatan desa yang direncanakan dan dilaksanakan sendiri oleh desa melalui Anggaran Pendapatan dan Belanja Desa (APBDes). Di desa Sardonoharjo, masyarakat berperan aktif dan selalu ingin tahu perkembangan yang terjadi di desa”.(Hasil wawancara dengan Kepala Desa 29 Juni 2018)

Sama halnya dengan informan dalam kaitan komitmen pemerintah untuk menumbuhkan tingkat partisipasi masyarakat, juga disampaikan oleh Sekretaris Desa:
“Kita sangat berusaha untuk akuntabel dan transparan mengenai apapun terkait dengan penggunaan dan baik itu dari Alokasi Dana Desa maupun APBDes .(Hasil wawancara dengan Sekretaris Desa, pada tanggal 8 Mei 2018)”

$\begin{array}{llr}\begin{array}{l}\text { Pendapat } \\ \text { menunjukkan }\end{array} & \begin{array}{l}\text { informan } \\ \text { bahwa }\end{array} & \begin{array}{r}\text { tersebut } \\ \text { dalam }\end{array} \\ \text { menumbuhkan } & \text { tingkat } & \text { partisipasi } \\ \text { masyarakat desa, khususnya } & \text { dalam } \\ \text { implementasi } & \text { program } & \text { ADD }\end{array}$
dilaksanakan secara keseluruhan dengan melibatkan seluruh aspek masyarakat dan pihak stakeholder dan secara komprehensif dalam menyelesaikan berbagai permasalahan di desa.

Sumber pendapatan desa yang penggunaannya terintegrasi dengan Anggaran Pendapatan Belanja Desa (APBDes). Oleh karena itu perencanaan program dan kegiatannya disusun melalui forum Musyawarah Perencanaan Pembangunan Dusun (Musrenbangdus) di bulan Oktober yang melibatkan seluruh lapisan masyarakat di tingkat pedukuhan. Dalam Musrengdus ada yang namanya penggalian gagasan dan direkap oleh Tim. Semua usulan yang dimusyawarahkan kemudian dirangkum sesuai dengan skala prioritas. Kemudian dilanjutkan ke Musyawarah Perencanaan Pembangunan Desa (Musrenbangdes). Musrenbangdes tersebut merupakan forum pembahasan usulan kegiatan pembangunan di tingkat desa yang berpedoman pada prinsip-prinsip Perencanaan Pembangunan Pasrtisipasi Masyarakat Desa. Musrengbandes melibatkan tokoh-tokoh, dan pamongpamong desa, meliputi Badan Permusyawaratan Desa (BPD), Lembaga 
Kemasyarakatan Desa (LKD), Lembaga Permusyawaratan Desa (LPMD) dan PKK. Dari usulan yang diajukan di Murenbangdes, sebagian ada yang di back up dalam APBDes tapi ada juga yang diusulkan ke SKPD dengan jalur Murenbangdes. Kemudian dirangkum dalam sebuah Dokumen Rencana Kerja Pembangunan Desa (RKPDes) tahunan.

Implementasi program ADD di

Desa Sardonoharjo juga dilaksanakan dalam rangka pemberdayaan masyarakat dan menekanan proses motivasi berpartisipasi dalam pembangunan desa. Pelaksanaan prinsip partisipasi tersebut juga telah dibuktikan dengan sambutan LPMD pada saat Musrenbangdes :

"Hasil Murenbangdus setelah digodog beberapa kali dan sudah disempurnakan, dengan proses tersebut di dalam Rencana Kerja Pemerintah Desa tidak terlalu banyak masalah. Tiap pedukuhan harus mulai mencatat program tahun selanjutnya maupun yang belum masuk dalam Rencana Pembangunan Jangka Menengah Desa, sehingga ketika nanti ada revisi RPJM Desa dapat langsung dikerjakan "(Sambutan LPMD dalam warta desa Sardonoharjo edisi Maret 2017).

"Masyarakat desa Sardonoharjo berkeinginan menjadi desa yang maju dan tidak mau ketinggalan informasi. Jadi setiap kali ada informasi dari kelurahan, masyarakat selalu update. Masyarakat mempunyai kesadaran dan oleh karena itu selalu ingin dilibatkan dalam pengambilan keputusan. Karena masyarakat sadar mereka adalah sebagai pelaku pembangunan yang nantinya akan diimplementasikan pada program ADD”(Hasil wawancara dengan warga dukuh Plumbon pada tanggal 9 Juli 2018).

Dari sisi transparansi perencanaan, Desa Sardonoharjo diwajibkan untuk memberikan informasi kepada masyarakatnya tentang kegiatan apa yang akan dilaksanakan yang bersumber dari ADD. Hal tersebut menunjukkan bahwa perencanaan ADD di desa Sardonoharjo juga telah melaksanakan penerapan bertahap prinsip transparansi dan akuntabilitas. Prinsip transparansi dijunjung tinggi oleh implementor program ADD di Desa Sardonoharjo sehingga diharapkan memperoleh imbal balik/tanggapan masyarakat dalam memperbaiki kinerja pembangunan. Pembangunan desa yang bersumber dari ADD dirangkum dalam warta desa Sardonoharjo. Warta desa Sardonoharjo adalah buletin yang diterbitkan oleh Desa Sardonoharjo setiap 2 bulan sekali sesuai dengan tahapan ADD dicairkan. Di dalam warta desa berisi infomasi lengkap tentang kegiatankegiatan desa dan aspirasi masyarakat.

"Satu-satunya desa di Ngaglik Sleman yang mempunyai warta desa hanya di desa Sardonoharjo. Warta desa kami terbitkan 2 bulan sekali. Semua pedukuhan dan RT diberikan warta desa. Masyarakat boleh menulis apapun, menyampaikan aspirasi apapun, dan menanyakan apapun terkait penggunaan Alokasi Dana Desa maupun dana lainnya”.(Wawancara dengan Kepala Desa , 10 Juli 2018)

"Terdapat papan pengumuman APBDes Desa Sardonoharjo di beberapa titik, hal ini merupakan bentuk transparansi Desa terhadap Dana Desa sehingga masyarakat dapat mengetahui 
bagaimana pengelolaan dana tersebut”. (Wawancara dengan Kepala Desa , 10 Juli 2018)

Pernyataan Kepala desa didukung oleh Sekretaris Desa sebagai berikut : "Selain warta desa sebagai bentuk transparansi, sebenarnya setiap desa di kecamatan Ngaglik wajib memasang papan informasi di kantor desa tentang rincian Alokasi Dana Desa agar masyarakat turut mengawasi kegiatan pemerintah desa sesuai bidangnya yang akan berlangsung satu tahun ke depan”.(Hasil wawancara dengan Sekertaris Desa 11 Juli 2018).

"Kami diberikan warta desa setiap dua bulan sekali dan menghadiri Musrenbangdus dan Musrenbangdes untuk kemudian dilanjut menyusun RKPDes. Saya rasa Desa Sardonoharjo sangat transparan dan informatif terkait perencanaan kegiatan desa yang bersumber dari Dana Alokasi Dana Desa maupun dana apapun.”(Hasil wawancara dengan Kepala Dukuh Plumbon 12 Juli 2018)

Hasil wawancara Pak Kepala Desa senada dengan wawancara Pak Dukuh

"Pemerintah Desa Sardonoharjo memang memasang papan pengumuman APBDes Desa Sardoharjo disetiap sudut desa yang ramai dan masyarakat desa sardonoharjo menyambut pemasangan ini sebagai bentuk transparasi desa”.(Hasil wawancara dengan Kepala Dukuh Plumbon 12 Juli 2018)

Pelaksanaan dari kegiatankegiatan yang pembiayaannya bersumber dari ADD sepenuhnya dilaksanakan oleh Tim Penanggungjawab Kegiatan. Tim dibentuk dari masyarakat dan perangkat desa Sardonoharjo. Guna mendukung keterbukaan dan penyampaian informasi secara jelas kepada masyarakat, ,maka setiap kegiatan fisik wajib dilengkapi dengan papan informasi kegiatan yang dipasang di lokasi kegiatan, papan informasi terebut sekurang-kurangnya memuat nama kegiatan, volume kegiatan , besaran anggaran dari ADD dan waktu pelaksanaan kegiatan.

Selain papan nama kegiatan, informasi tentang seluruh program ADD wajib disajikan di kantor desa yang dapat diakses oleh masyarakat desa. Kedua hal tersebut dilakukan dalam rangka melaksanakan prinsip transparansi pembangunan desa, sehingga masyarakat secara bebas dapat mengetahui tentang program ADD maupun memberi kritik dan saran kepada Tim Penanggungjawab Kegiatan demi kesempurnaan pengelolaan ADD.

"Rincian ADD yang tertuang dalam APBDes bukan merupakan suatu rahasia. Kami dari pemerintah daerah mempersilahkan warga bagi yang mau melihat ataupun meminjam dokumen tersebut untuk dipelajari lebih lanjut."(Hasil wawancara dengan Kaur Perencanaan tanggal 10 Agustus 2018)

Pendapat tersebut juga disambut positif oleh salah satu anggota PKK Sardonoharjo, yang dibuktikan dengan wawancara sebagai berikut :

"Warga kami sangat antusias jika diminta pendapat maupun usulan dan masukan untuk kepentingan pembangunan desa agar lebih maju. Informasi sangat terbuka dan warga tidak dibohongi masalah penggunaan dana pemerintah.”(Hasil wawancara dengan 
anggota PKK pada tanggal 13 Agustus 2018)

Dari pendapat tersebut dapat dikaji bahwa prinsip partisipatif pembangunan masyarakat desa benarbenar ditumbuh kembangkan yang juga diikuti transparansi mulai dari perencanaan penggunaan dana. Demikian pula dalam hal pelaksanaan program ADD di Desa Sardonoharjo juga menjunjung tinggi prinsip partisipatif dalam pengambilan keputusan dan transparansi, sebagaimana disampaikan informan sebagai berikut :

"Kami mengajak warga untuk melakukan koordinasi terkait pelaksanaan Alokasi Dana Desa tergantung bidang dan tupoksi masing-masing melaporkan kegiatan. Partisipasi masyarakat di desa bisa berupa barang maupun tenaga. Misalkan dari pedukuhan mengusulkan pembuatan drainase dan disetujui untuk didanai kemudian diukur oleh Tim yang terdiri dari masyarakat dan perangkat desa, Tim mulai melakukan pengukuran dan dibuatkan RAB . Partisipasi masyarakat yang berupa belanja barang bisa dilakukan 2 mekanisme, bisa dibelanjakan masyarakat sendiri yang penting dikumpulkan notanya dan dibuat SPJ maupun dibelanjakan oleh Tim "(Hasil wawancara dengan Kepala Desa, 10 Juli 2018 )

Hasil wawancara tersebut diperkuat oleh pendapat warga sebagai berikut :

"Pak Kepala Desa setiap bulan mengadakan koordinasi dengan warga terkait dengan Alokasi Dana Desa, sudah sampai sejauh mana pelaksanaannya tiap bidang. Selain itu juga ada evaluasi pelaksanaan kegiatan.” (Hasil wawancara dengan warga desa 3 Agustus 2018)

Hasil wawancara tersebut sesuai dengan konsep transparansi yaitu dapat diketahui oleh banyak pihak (yang berkepentingan) mengenai perumusan kebijakan (politik) dari pemerintah, organisasi, badan usaha.

Dari sisi penerapan prinsip akuntabilitas pelaksanaan ADD ditempuh melalui sistem pelaporan yaitu laporan bulanan dan laporan masing-masing tahapan kegiatan.

"Sistem pelaporan dilaksanakan Tim Penanggung Jawab Kegiatan dengan menggunakan format yang telah ditetapkan, pelaporan tersebut dilaksanakan secara rutin, setiap bulan dan setiap akhir pelaksanaan tahapan kegiatan. Kami selalu mengingatkan untuk menyusun laporan kegiatan berdasarkan format yang ada setiap awal dan akhir tahapan kegiatan.Hal ini sebagai syarat untuk pengajuan anggaran tahap berikutnya”(Hasil wawancara dengan Kepala Desa, pada tanggal 22 Agustus 2018)

Pendapat tersebut didukung oleh pengelola ADD di tingkat desa, sebagaimana hasil wawancara berikut ini :

"Setiap bulan kami membuat laporan sesuai dengan petunjuk yang ada, karena tanpa adanya laporan, anggaran tahap berikutnya tidak direalisasikan” (Hasil wawancara dengan anggota Tim PenanggungJawab Kegiatan, pada tanggal 30 Agustus 2018)

Hasil wawancara tersebut menunjukkan bahwa dalam pelaksanaan ADD senantiasa dilaporkan perkembangan pelaksanaan kegiatan oleh 
pengelola tingkat desa, terutama perkembangan kegiatan fisik dan penyerapan dana, dengan demikian dapat diketahui bahwa tanggungjawab pengelola ADD tingkat desa sudah memenuhi ketentuan pembuatan laporan bulanan dan laporan akhir kegiatan.

Pertanggungjawaban program ADD kepada pemerintah tingkat atasnya dilakukan melalui sistem pelaporan yang dilakukan secara periodik. Laporan pelaksanaan ADD terdiri dari laporan pendahuluan, laporan masing-masing tahap kegiatan, laporan bulanan, dan laporan akhir kegiatan yang disusun secara komprehensif.

Akuntabilitas merupakan suatu perwujudan kewajiban seseorang atau kelompok dalam suatu unit organisasi untuk mempertanggungjawabkan setiap kegiatan dalam hal pengelolaan dan pengendalian sumber daya dan pelaksana kebijakan yang dimandatkan kepadanya dalam rangka untuk mencapai tujuan yang telah ditetapkan. Apabila hal ini dikaitkan dengan pelaksanaan tingkat tingkat partisipasi masyarakat desa melalui implementasi program ADD di Desa Sardonoharjo, maka prinsip akuntabilitas tersebut secara bertahap sudah mulai diterapkan dan sudah menunjukkan adanya komitmen yang sangat kuat untuk melaksanakan tanggungjawab sesuai dengan kapasitas dan kedudukannya.

Pertanggungjawaban ADD di Desa Sardonoharjo terintegrasi dengan pertanggungjawaban APBDes. Hal ini sesuai dengan Peraturan Bupati Nomor 4 Tahun 2016 tentang Pengelolaan Keuangan Desa.Peraturan Daerah tersebut dimaksudkan untuk memberikan landasan hukum bidang keuangan desa, dan anggaran pendapatan dan belanja desa.

Penguatan keuangan desa untuk menguatkan pilar transparansi dan akuntabilitas. Pengelolaan keuangan desa harus dilakukan secara efisien dan efektif, transparan dan akuntabel. ADD yang merupakan salah satu sumber utama pendapatan desa juga harus dipertanggungjawabkan secara transparan kepada masyarakat maupun kepada pemerintah tingkat atasnya sebagai institusi pemberi kewenangan."Dalam pertanggungjawaban administrasi, kadang ada kendala, terlebih sekarang menggunakan Sistem Keuangan Desa (SISKUDES) dari Pemkab yang sangat rigid, yang mana ketika salah menginput berarti harus mengulang dari awal. Pihak desa diberikan Bimbingan Teknis (Bimtek) dari pihak propinsi, kabupaten maupun pendampingan dari kecamatan. Kendala lain dari pihak masyarakat sendiri contohnya keterlambatan penyampaian SPJ dari pedukuhan, ada kuitansi-kuitansi yang keselip sehingga memerlukan taksiran sesuai nilai wajar. Pihak desa masih terus belajar untuk penyempurnaan pembuatan laporan”.(Hasil wawancara dengan Kepala Desa 10 Juli 2018)

Kutipan wawancara tersebut menunjukkan bahwa selama dalam pelaksanaan ADD tetap dituntut pertanggungjawaban pada setiap pembelanjaan uang ADD. Dengan demikian apabila hal tersebut dilakukan secara terus menerus dan tertib sesuai ketentuan yang berlaku maka dapat meringankan serta mendukung dari penyusunan pertanggungjawaban akhir 
kegiatan ADD yang harus disusun oleh Tim Penangggungjawab Kegiatan. Aparat Kecamatan melakukan pendampingan dan pembinaan dalam rangka menuju tertib administrasi pada setiap kesempatan yang ada.

Hasil-hasil pembangunan dapat disajikan hasil-hasil pembangunan yang berupa fisik/infrastruktur Desa Sardonoharjo sebagaimana tabel berikut:

Pengukuran Kinerja Keuangan Alokasi Dana Desa menggunakan rumus Rasio Efektivitas :

Rasio $=\frac{\text { Realisasi Anggaran Belanja }}{\text { Target Anggaran Belanja }} \times 100 \%$

Sumber : Abdul Halim (2012)

Kriteria tingkat efektifitas anggaran belanja sebagai berikut :

1. Jika hasil perbandingan lebih dari $100 \%$, maka dikatakan sangat efektif.

2. Jika hasil perbandingan antara 90\% $100 \%$, maka dikatakan efektif.

3. Jika hasil perbandingan antara $80 \%$ 90\%, maka dikatakan cukup efektif.

4. Jika hasil perbandingan antara $60 \%$ 80\%, maka dikatakan kurang efektif.

5. Jika hasil perbandingan dibawah $60 \%$ maka dikatakan tidak efektif

Data tersebut menunjukkan bahwa hasil yang dicapai di Desa Sardonoharjo rata-rata baik sehingga secara fisik dapat dipertanggungjawabkan. Terlihat dari tabel 1. tingkat penyelesaian rata-rata sebesar 97\% dan menunjukkan kinerja efektifitas anggaran belanja di Desa Sardonoharjo dikatakan sangat efektif. Sedangkan secara administrasi perlu adanya perbaikan dan pembenahan untuk kesempurnaan penerapan prinsip akuntabilitas.

Dengan dilakukannya prinsip akuntabilitas secara bertahap akhirnya akan mendukung kepercayaaan masyarakat terhadap pelaksanaan pembangunan desa yang pada akhirnya akan tercapai tingkat partisipasi masyarakat desa yang secara komulatif akan mendukung keberhasilan pembangunan daerah.

Evaluasi pelaksanaan program ADD membimbing masyarakat untuk terus berpatisipasi aktif dalam memberikan masukan dan koreksi pelaksanan ADD. Dalam hal in pemerintah desa juga harus merespon koreksi masyarakat dalam forum tersebut sehungga tercipta kesempurnaan pelaksanaan ADD. Implementasi pelaksanaan ADD ini sesuai dengan prinsip partisipasi (Tjokroamidjojo, 2010) adalah keterlibatan setiap waraga Negara dalam pengmbilan keputusan baik secara langsung maypun melalui institusi yang mewakili kepentingannya. Selain itu juga sesuai dengan responsiveness (Tjokroamidjojo, 2010) diartikan bahwa lembaga-lembaga Negara/badan usaha harus berusaha untuk melayani stakeholders, responsif terhadap aspirasi masyarakat dan kepentingan klien.

Dari hasil penelitian tersebut di atas dapat dirangkum bahwa sistem Akuntabilitas Pengeloaan Alokasi Dana Desa di wilayah Desa Sardonoharjo sudah berdasarkan prinsip tanggung gugat maupun prinsip tanggungjawab, walaupun belum sepenuhnya sempurna. Sedangkan yang berkaitan dengan pengelola Alokasi Dana Desa yang 
melaksanakan pengelolaan administrasi keuangan masih perlu diupayakan pendampingan dan pembinaan di tingkat pedukuhan.

Table 1.

Tabel Penggunaan Alokasi Dana Desa di Desa Sardonoharjo 2017

\begin{tabular}{|c|c|c|c|c|c|}
\hline No & Keterangan & $\begin{array}{l}\text { Realisasi } \\
\text { Penggunaan } \\
\text { Dana Desa }\end{array}$ & $\begin{array}{l}\text { Target Alokasi } \\
\text { Dana Desa }\end{array}$ & Persentase & $\begin{array}{l}\text { Tingkat } \\
\text { Efektifitas }\end{array}$ \\
\hline 1 & $\begin{array}{l}\text { Penghasilan dan } \\
\text { Tunjangan Kepala } \\
\text { Desa dan Perangkat }\end{array}$ & Rp639.350.500 & Rp687.480.000 & $93 \%$ & efektif \\
\hline 2 & Insentif & Rp62.400.000 & Rp62.400.000 & $100 \%$ & efektif \\
\hline 3 & Penyusunan SOTK & Rp1.995.000 & Rp2.850.000 & $70 \%$ & kurang efektif \\
\hline 4 & Terbitan Majalah & Rp19.365.000 & Rp19.963.000 & $97 \%$ & efektif \\
\hline 5 & $\begin{array}{l}\text { Peningkatan Kapasitas } \\
\text { Aparatur Daerah }\end{array}$ & Rp1.970.000 & Rp2.815.000 & $70 \%$ & kurang efektif \\
\hline 6 & Fasilitas Akte Kematian & Rp13.007.000 & Rp14.300.000 & $91 \%$ & efektif \\
\hline 7 & Pendapatan Penduduk & Rp18.307.000 & Rp18.684.000 & $98 \%$ & efektif \\
\hline 8 & $\begin{array}{l}\text { APBDes dan } \\
\text { Perubahannya }\end{array}$ & Rp7.541.200 & Rp7.650.000 & $99 \%$ & efektif \\
\hline 9 & $\begin{array}{l}\text { Laporan Realisasi } \\
\text { APBDes }\end{array}$ & Rp4.400.000 & Rp4.432.000 & $99 \%$ & efektif \\
\hline 10 & $\begin{array}{l}\text { Laporan } \\
\text { Pertanggungjawaban } \\
\text { APBDes }\end{array}$ & Rp2.803.600 & Rp2.950.000 & $95 \%$ & efektif \\
\hline 11 & Musrenbang Desa & Rp20.305.000 & Rp20.305.000 & $100 \%$ & efektif \\
\hline 12 & Penyusunan RKPDesa & Rp6.855.000 & Rp6.900.000 & $99 \%$ & efektif \\
\hline 13 & $\begin{array}{l}\text { Pengangkatan Dukuh dan } \\
\text { Kasi/Kaur }\end{array}$ & Rp70.878.000 & Rp70.878.000 & $100 \%$ & efektif \\
\hline 14 & $\begin{array}{l}\text { Operasional Poskesdes } \\
\text { dan Bukti } \\
\text { Sosial }\end{array}$ & Rp11.030.000 & Rp11.500.000 & $96 \%$ & efektif \\
\hline 15 & Penyuluhan PKK & Rp1.900.000 & Rp2.000.000 & $95 \%$ & efektif \\
\hline 16 & $\begin{array}{l}\text { Balai Padukuhan, Kantor } \\
\text {, dan Mushola }\end{array}$ & Rp591.930.800 & Rp591.930.800 & $100 \%$ & efektif \\
\hline
\end{tabular}


JURNAL LITBANG SUKOWATI | VOLUME 2 | NOMOR 1 | TAHUN 2018 | HAL. 89 - 105

\begin{tabular}{|c|c|c|c|c|c|}
\hline No & Keterangan & $\begin{array}{l}\text { Realisasi } \\
\text { Penggunaan } \\
\text { Dana Desa }\end{array}$ & $\begin{array}{l}\text { Target Alokasi } \\
\text { Dana Desa }\end{array}$ & Persentase & $\begin{array}{l}\text { Tingkat } \\
\text { Efektifitas }\end{array}$ \\
\hline 17 & $\begin{array}{l}\text { Pemeliharaan dan } \\
\text { Pembangunan } \\
\text { Gedung TK }\end{array}$ & Rp56.097.500 & Rp56.097.500 & $100 \%$ & efektif \\
\hline 18 & Rehab Gedung Polindes & Rp24.628.000 & Rp24.800.000 & $99 \%$ & efektif \\
\hline 19 & Operasional PKK Desa & Rp50.920.700 & Rp50.920.700 & $100 \%$ & efektif \\
\hline 20 & $\begin{array}{l}\text { Operasional LPMD dan } \\
\text { Pembinaan } \\
\text { LPMD Sub Unit }\end{array}$ & Rp29.620.000 & Rp30.000.000 & $99 \%$ & efektif \\
\hline 21 & $\begin{array}{l}\text { Operasional Karang } \\
\text { Taruna }\end{array}$ & Rp17.788.000 & Rp17.967.000 & $99 \%$ & efektif \\
\hline 22 & Pembinaan Linmas & Rp19.635.000 & Rp19.874.000 & $99 \%$ & efektif \\
\hline 23 & $\begin{array}{l}\text { Pembinaan Ro'is dan } \\
\text { Takmir }\end{array}$ & Rp16.539.500 & Rp16.706.000 & $99 \%$ & efektif \\
\hline 24 & Pengajian Rutin PKK & Rp1.000.000 & Rp1.000.000 & $100 \%$ & efektif \\
\hline 25 & Lomba Desa & Rp9.270.000 & Rp10.270.000 & $90 \%$ & efektif \\
\hline 26 & $\begin{array}{l}\text { Lomba Masak dan Lomba } \\
\text { Antar Padukuhan }\end{array}$ & Rp4.000.000 & Rp4.081.000 & $98 \%$ & efektif \\
\hline 27 & Peringatan HUT RI & Rp10.994.500 & Rp11.000.000 & $100 \%$ & efektif \\
\hline 28 & $\begin{array}{l}\text { Sosialisasi UU } \\
\text { Perkawinan }\end{array}$ & Rp700.000 & Rp796.820 & $88 \%$ & cukup efektif \\
\hline & Jumlah & Rp1.715.231.300 & Rp1.770.550.820 & $97 \%$ & efektif \\
\hline
\end{tabular}

\section{SIMPULAN}

Sistem Pengelolaan Alokasi Dana Desa di Sardonoharjo Kecamatan Ngaglik Kabupaten Sleman, dapat diambil beberapa kesimpulan sebagai berikut :

1. Sistem Pengelolaan Alokasi Dana Desa di Desa Sardonoharjo telah menerapkan prinsip-prinsip Good Governance yaitu Partisipasi Masyarakat (Participation), Tegaknya Supremasi Hukum (Rule of Law), Transparansi (Transparency),
Peduli pada Stakeholder/Dunia Usaha, Berorientasi pada Konsensus (Consensus), Kesetaraan (Equity), Efektifitas dan Efisiensi (Effectiveness and Efficiency), Akuntabilitas (Accountability), dan Visi Strategis (Strategic Vision).

2. Tahapan Pengelolaan Alokasi Dana Desa menerapkan Perencanaan, Pelaksanaan dan Pertanggungjawaban Alokasi Dana Desa secara teknis maupun administrasi sudah cukup baik, dimana 
a. Perencanaan program ADD (Alokasi Dana Desa) secara bertahap telah melaksanakan konsep pembangunan partisipatif masyarakat desa yang dibuktikan dengan penerapan prinsip partisipatif, responsif, transparansi guna pembelajaran sumber daya masyarakat desa dalam rangka mewujudkan pemberdayaan masyarakat desa melalui forum Musrengdus Musyawarah Perencanaan Pembangunan Dusun (Musregdus) kemudian dilanjutkan Musrenbangdes (Musyawarah Perencanaan Pembangunan Desa). Prinsip transparansi dibuktikan dengan diterbitkannya warta desa setiap dua bulan sekali berisi rangkuman tentang rencana kegiatan desa Sardonoharjo dan Papan Pengumuman APBDes Desa Sardonoharjo yang dipasang disetiap Dusun.

b. Pelaksanaan program ADD (Alokasi Dana Desa) di Desa
Sardonoharjo telah menerapkan prinsip-prinsip partisipatif, responsif, transparan. Ini dibuktikan dengan adanya kegiatan yang terlaksana dengan baik dalam pelaksanaan alokasi dana desa.

c. Pertanggungjawaban ADD baik secara teknis maupun administrasi sudah baik dibuktikan dengan publikasi papan pengumuman laporan keuangan disetiap dukuh, namun dalam hal pertanggungjawaban administrasi terkendala dengan keterlambatan laporan dari pedukuhan dan pihak desa agak kesulitan dalam menerapkan Sistem Keuangan Desa (SISKEUDES).

3. Kinerja Keuangan Desa Sardonoharjo tahun 2017 tingkat efektifitasnya adalah Efektif dengan persentase sebesar $97 \%$ dimana target alokasi dana desa mendekati dengan realisasi penggunaan dana sehingga alokasi dana desa terserap dengan baik.

\section{DAFTAR PUSTAKA}

Elgia, Astuti. (2012). Akuntabilitas Pemerintah Desa dalam Pengelolaan Anggaran Penerimaan dan Belanja (APBDesa) (Studi pada Alokasi Dana Desa (ADD) Tahun 2011 di Desa Sorong Kecamatan Geger Kabupaten Madiun. PPS Universitas Negeri Surabaya.

Moleong, Lexy. (2010). Metodologi Penelitian Kualitatif. Bandung : PT Remaja Putra

Nurul, Rigel. (2017). Akuntabilitas Dana Desa (Studi Kasus Pengelolaan Alokasi Dana Desa Di Desa Wijirejo Kecamatan Pandak Bantul Tahun 2016/2017). Universitas’Aisyiyah Yogyakarta.

Permendagri Nomor 21 Tahun 2011 Tentang Pedoman Pengelolaan Keuangan Daerah. 
Thomas. (2013). Pengelolaan Alokasi Dana Desa Dalam Upaya Meningkatkan Pembangunan Di Desa Sebawang Kecamatan Sesayap Kabupaten Tana Tidung. EJournal Pemerintahan Integratif

Smith,Jonathan A., Flowers, Paul., and Larkin. Michael . (2009). Interpretive phenomenological analysis : Theory, method and research. Los Angeles, London, New Delhi, Singapore, Washington : Sage.

Solekhan, Moch. (2012). Penyelenggaraan Pemerintahan Desa Berbasis Partisipasi Masyarakat dalam Membangun Mekanisme Akuntabilitas. Malang : Setara Press.

Yunianty, Umi. (2015). Analisis Efisiensi dan Efektivitas Anggaran Pendapatan Belanja Desa (APBDesa). Seminar Nasional Universitas PGRI Yogyakarta. ,Undang-Undang Nomor 6 Tahun 2014 Tentang Desa. 